\title{
IMPROVING THE VOCABULARY MASTERY THROUGH WORD-CONNECTION GAME
}

\author{
Novalia Tanasy \\ Universitas Muslim Maros, \\ novalia@umma.ac.id, \\ Nuraliah Ali \\ Universitas Muslim Maros, \\ alyaery@umma.ac.id
}

\begin{abstract}
This research aimed at finding (1) whether the use of Word-Connection game significantly improved the students vocabulary mastery of the first grade students of English Education in Universitas Muslim Maros on academic year 2018/2019, and (2) their attitudes toward the use of this game. Method of this research was experiment with 2 classes as the samples. It employed 30 numbers of vocabulary test then analyzed by using inferential statistic SPSS program 25.0 and 20 numbers of close-ended questions questionnaire to find out their attitude towards the use of Word-Connection game. Result of the research shows that the mean score improved significantly at the experiment group from 3.476 to 8.356 , but at the control group only from 3.950 to 4.550 . Standard deviation at experiment group decreased from 1.2444 to 0.9238 and at control group from 1.5472 to 1.7604 . Range on normalized gain score at the experiment group was 0.37 , smaller than control group which was 0.43 . Standard deviation on normalized gain score at experiment group was 0.115511 whereas at control group was 0.11075 . Furthermore, data which were collected from questionnaire indicated that the students had positive attitude toward the use of WordConnection game with mean score 82.68. Findings above concludes that the use of Word-Connection game can improve the students vocabulary mastery at the experimental group.
\end{abstract}

Keywords: Word-Connection game, vocabulary, attitude

\section{A. INTRODUCTION}

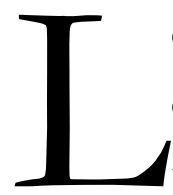

earning English is not as easy as one might expect. Many students face difficulties to express their minds, ideas, feelings and experiences because they always lost their words to say and just blank. They sometimes also do not understand the meaning of some words so they miss the point of some information. The worst effect of such situations will create disconnection between the speakers and the listeners. Accumulation of these bitter facts may happen because their lacking in vocabulary. Vocabulary learning as an essential part in foreign language learning, whether in books or in classrooms is also central to the teaching and importance of language to language learners (Alqahtani, 2015).

Properly, vocabulary skills are taught to the students in the early stage of learning English, because this skill is the basic weapon for them to write or speak. Without any structure needed, learning vocabulary become the easiest subject in English department. This is why when the 


\section{Volume 5, Number 02, December 2019}

students mastered sufficient vocabulary, it will be easier for them to master the four micro language skills that are reading, speaking, listening and writing.

The fact that the students are getting low interest in learning vocabulary caused by the thought that vocabulary has so many words which will be difficult to understand if the people didn't know about the function of it. It is realized that to express something we need more than one word to make people understand and to make the sentences clear in the language learning of vocabulary (Rizki et al, 2013). The monotonous method used by the teachers or the classroom situation like custom of speaking with regional language especially in village (Maros for example), also take parts in deficiency interest. These all hit the students' motivation to learn vocabulary whereas we all know that motivation is one of the greatest supplements in learning English. Some of them do better because they are better motivated.

Objectives of this research were studied as follows (1) to describe the significant improvement of vocabulary mastery of the first grade students of English Education in Universitas Muslim Maros on academic year 2018/2019 by using Word-Connection game, and (2) to describe their attitudes toward the use of this game.

\section{B. REVIEW OF LITERATURE}

Generally, teaching and learning cannot be separated from what we call interaction. The interaction can exist if the process of teaching and learning well done. Learners often instinctively recognize the importance of vocabulary to their language. Motivation, aptitude and learning strategies are important individual factors influencing on a learner's language acquisition (Akdogan, 2018). According to Oxford and Nyikos (in Nirattisai, 2014), vocabulary learning strategies are methods that allow learners to enhance their learning autonomy, independence, and self-direction so the level of vocabulary learning strategy use highly depend on the students themselves. Students with more control of their own learning will employ strategies more frequently.

The students and the teachers need solutions directly to feel the advantages of learning materials by experiencing and learning vocabulary. One strategy in developing it is by playing games. Playing games is considered effective because the teachers indirectly put an element of fun to excite the students who are bored with the material. Yip and Kwan (in Aghlara et al, 2011) suggested that students who used games for their learning became more successful in learning new words compared to those who learned the same vocabulary through traditional method. Moreover, Scrivener in Derakhshan \& Khatir (2015) stated that by using vocabulary games, learning process 
is going to be more valuable, this method can make vocabulary learning more enjoyable, so it can help students to retain target words more quickly. Similarly, Aslanabadi and Rasouli (2013) found that game is not only bring fun for learners to the class, but they also motivate learners and improve their confidence.

Word-Connection game is a game which surely can motivate the students to learn English. Here, they will try to figure out what the words behind the letters. Actually, the writers were inspired by two famous games on television which are "Kata Berkait" and "Komunikata", then they combine these two games into one excited activity. This game is played by two or more groups (1015 people for each) and takes their concentration about vocabulary. Each group will have several minutes to read some articles and understand the words (especially new or uncommon words) before playing the game. Then they will ask the letter by letter to guess the secret words and finally the most excellent group will join the bonus phase.

Based on the study results above, we can conclude that learning vocabulary through games is one effective and interesting way that we can apply in the classrooms. But the teachers should monitor their students to make sure that the structure and rules of the game are applied well and fair. Teachers also should encourage students to take advantage of games in their learning process, not just playing the game and let it take higher rank over the learning purpose.

\section{METHOD}

Method of this research was experiment and manipulated the condition to find out a certain result such as students vocabulary achievement and attitude. It employed two groups as the research subjects, class $1 \mathrm{~A}$ as the experiment group and was treated by using Word-Connection game, the other group was class 1B as the control group and didn't taught by the game, but still they were taught vocabulary by using conventional method. Independent variable of this research was the use of Word-Connection game and the dependent variable was the students' achievement and attitude.

\section{Instrument}

There were two instruments used in this research as follows: (1) vocabulary test, the students were tested through pretest and posttest which consist of 30 numbers multiple choices to measure their achievements in mastery vocabulary, (2) questionnaire, consist of 20 numbers of close-ended questions which can explore the student's attitude in the learning process, especially towards the use of Word-Connection game. 


\section{Volume 5, Number 02, December 2019}

\section{Procedure}

Before starting the treatment, pretest which consist of 30 numbers of vocabulary test were given to experiment and control groups, time duration was 90 minutes. Then the treatment called Word-Connection game were held within 14 meetings, mostly at the end of the meetings. The treatment procedures consist of 3 phases, $1_{\text {st }}$ phase started by presentation where the writers explained material about vocabulary, then explained and included the Word-Connection game, then divided the students into 4 groups (6-7 students per group). $2^{\text {nd }}$ phase was practice, the writers applied Word-Connection game and explained the clues about the topic question which was taken from the lesson material only. There, some slides showed a big table which consist of 7 lines, the first and the last lines filled by the a word, each group had their turn to open the letter then guessing the hidden word. The two winning groups would enter bonus phase where they had to mention 5 Secret Words related to the Key Word. The 3 rd phase was production, here the writers asked the meaning of all the words presented in the game, then the students mentioned and spelled the letters 1 by 1 perfectly and fastly. After presenting the materials and treatments, the writers applied posttest about 30 numbers (the test questions and procedures were the same with the pretest for both groups). A questionnaire also was given after that at the experiment group to get measurement result toward the use of Word-Connection game in learning vocabulary which consist of 20 numbers close-ended questions.

\section{Data analysis}

The data were collected and analyzed by following these procedures:

a. The vocabulary tests consisted 30 numbers of multiple choice questions. The students get 3 score for every correct answer. If a student answers all this test correctly, his total score is 10. We calculated the students' result by applying the formula below. Then the minimum and maximum scores could be seen.

A student score $=$ the score gained the maximum score $\mathrm{x} 10$ (Gay, 2012)

b. Classifying the students' pretest and posttest scores into 7 categories as follows: 
Novalia Tanasy, Nuraliah Ali, Improving the Vocabulary mastery...

Table 1. Scoring classification

\begin{tabular}{lc}
\hline Score & Category \\
\hline $9.6-10$ & Excellent \\
$8.6-9.5$ & Very good \\
$7.6-8.5$ & Good \\
$6.6-7.5$ & Fairly good \\
$5.6-6.6$ & Fair \\
$3.6-5.5$ & Poor \\
$0-3.5$ & Very poor \\
\hline
\end{tabular}

c. Calculating the Range, Mean and Standard deviation of pretest and posttest by using program SPSS 25.0.

d. Calculating the Normalized gain score of pretest and posttest with formula as follows: $<\mathrm{g}>=$ pretest or postest score10-pretest score

where: $<\mathrm{g}>=$ normalized gain score (Widyoko, 2009)

e. After distributing the questionnaire at the experiment group and calculate the result, the data were analyzed by using the percentage analysis formula below:

$$
\begin{aligned}
\mathrm{p}=\mathrm{fqNx} 100 \% & \\
\text { where: } \mathrm{p} & =\text { percentage } \\
\mathrm{fq} & =\text { number of frequency } \\
\mathrm{n} & =\text { number of respondents (Sugiyono, 2015) }
\end{aligned}
$$

f. Then the result classified based on Likert scale as follows: 
Volume 5, Number 02, December 2019

Table 2. Attitude scoring classification

\begin{tabular}{ll}
\hline SCORE & CLASSIFICATION \\
\hline $85-100$ & Strongly positive \\
$69-84$ & Positive \\
$53-68$ & Fairly positive \\
$37-52$ & Negative \\
$20-36$ & Strongly negative \\
\hline
\end{tabular}

(Tanasy, 2017)

g. Determining the mean score of the students' attitude based on the questionnaire at experiment group by employing this formula:

$$
\mathrm{M}=\mathrm{XN}
$$

$$
\text { where: } \begin{aligned}
\mathrm{M} & =\text { questionnaire mean score } \\
& =\text { total number of the questionnaire scores } \\
\mathrm{N} & =\text { total number of the students }
\end{aligned}
$$

(Abidin\&Purbawanto, 2015)

\section{FINDINGS AND DISCUSSION}

\section{Finding}

This research was held in Campus 2 Universitas Muslim Maros, Kokoa Pamelakkang Je'ne street, Allepolea district, Lau sub-district, Maros regency at the $1_{\text {st }}$ semester of English Education Department, year academic 2018-2019 which contains of 2 classes, class 1A as the treatment group and $1 \mathrm{~B}$ as the control group. Data result about pretest and posttest regarding their achievement in learning vocabulary before and after employing the Word-Connection game are described as follows:

a. After calculating the pretest and posttest results, some data were gathered from minimum to maximum. Table below illustrates it:

Table 3. The minum and maximum test' scores

\begin{tabular}{ccccc}
\hline Classification & $\begin{array}{c}\text { Pretest experiment } \\
\text { group }\end{array}$ & $\begin{array}{c}\text { Posttest experiment } \\
\text { group }\end{array}$ & $\begin{array}{c}\text { Pretest control } \\
\text { group }\end{array}$ & $\begin{array}{c}\text { Posttest control } \\
\text { group }\end{array}$ \\
\hline Minimum & 2.0 & 6.8 & 2.0 & 2.0
\end{tabular}


From the table above, we can see that the pretest minimum score at experiment group increased from 2.0 to 6.8 on the posttest, meanwhile at control group the pretest minimum score was 2.0 and did not change on posttest. The same things happened in maximum scores on pretest and posttest as well, where at the experiment group it significantly improved from 6.1 to 9.8 , but at control group the improvement was little, which from 6.3 to 7.7 only.

b. Classifying the students pretest and posttest into 7 categories below:

Table 4. The classification and the rate percentage of the students pretest score

\begin{tabular}{|c|c|c|c|c|c|}
\hline \multirow{2}{*}{ Classification } & \multirow{2}{*}{ Score } & \multicolumn{2}{|c|}{ Experiment group } & \multicolumn{2}{|c|}{ Control group } \\
\hline & & $\mathrm{F}$ & $\%$ & $\mathrm{~F}$ & $\%$ \\
\hline Excellent & $9.6-100$ & - & - & - & - \\
\hline Very good & $8.6-9.5$ & - & - & - & - \\
\hline Good & $7.6-8.5$ & - & - & - & - \\
\hline Fairly good & $6.6-7.5$ & - & - & - & - \\
\hline Fair & $5.6-6.5$ & 3 & $12 \%$ & 5 & $21 \%$ \\
\hline Poor & $3.6-5.5$ & 3 & $12 \%$ & 6 & $25 \%$ \\
\hline Very poor & $0-3.5$ & 19 & $76 \%$ & 13 & $54 \%$ \\
\hline Total & & 25 & $100 \%$ & 24 & $100 \%$ \\
\hline
\end{tabular}

Based on the table above, the pretest result at experiment group were classified as Very poor 19 students (76\%), Poor 3 students (12\%) and Fair 3 students (12\%). None of the students classified as Fairly good, Good, Very good or Excellent. While on the control group, the students were classified as Very poor 13 students (54\%), Poor 6 students (25\%) and Fair 5 students (21\%). But none of them also classified as Fairly good, Good, Very good or Excellent. 


\section{Volume 5, Number 02, December 2019}

But after giving the treatment name Word-Connection game to experiment group, the students score were amazingly improve. Only 3 students (12\%) were classified as Fairly good, 12 students $(48 \%)$ as Good, 6 students $(24 \%)$ as Very good and 4 students (16\%) as Excellent. Meanwhile at the control group, eventhough they also got improvement, but those are not so significant. There were still 10 students classified as Very poor (42\%), Poor 5 students (21\%), Fair 6 students (25\%), Fairly good 1 student (4\%) and Good 2 students (8\%). None of them classified as Very good or Excellent.

Table 5. The classification and the rate percentage of the students posttest score

\begin{tabular}{|c|c|c|c|c|c|}
\hline \multirow{2}{*}{ Classification } & \multirow{2}{*}{ Score } & \multicolumn{2}{|c|}{ Experiment group } & \multicolumn{2}{|c|}{ Control group } \\
\hline & & $\mathrm{F}$ & $\%$ & $\mathrm{~F}$ & $\%$ \\
\hline Excellent & $9.6-100$ & 4 & $16 \%$ & - & - \\
\hline Very good & $8.6-9.5$ & 6 & $24 \%$ & - & - \\
\hline Good & $7.6-8.5$ & 12 & $48 \%$ & 2 & $4 \%$ \\
\hline Fairly good & $6.6-7.5$ & 3 & $12 \%$ & 1 & $4 \%$ \\
\hline Fair & $5.6-6.5$ & - & - & 6 & $25 \%$ \\
\hline Poor & $3.6-5.5$ & - & - & 5 & $21 \%$ \\
\hline Very poor & $0-3.5$ & - & - & 10 & $42 \%$ \\
\hline Total & & 25 & $100 \%$ & 24 & $100 \%$ \\
\hline
\end{tabular}

b. Calculation of the Range, Mean and Standard deviation of pretest and posttest from students' at experiment and control group were derived from SPSS program 25.0 and illustrated as table below. 
Novalia Tanasy, Nuraliah Ali, Improving the Vocabulary mastery...

Table 6. Descriptive Statistics

\begin{tabular}{|c|c|c|c|c|c|}
\hline Statistics & Pretest Experiment group & $\begin{array}{l}\text { Posttest Experiment } \\
\text { group }\end{array}$ & $\begin{array}{l}\text { Pretest } \\
\text { Control } \\
\text { group }\end{array}$ & $\begin{array}{c}\text { Posttest } \\
\text { Control } \\
\text { group }\end{array}$ & Valid N (listwise) \\
\hline $\mathrm{N}$ & 25 & 25 & 24 & 24 & 24 \\
\hline Range & 4.1 & 3.0 & 4.3 & 5.7 & - \\
\hline Minimum & 2.0 & 6.8 & 2.0 & 2.0 & - \\
\hline Maximum & 6.1 & 9.8 & 6.3 & 7.7 & - \\
\hline Sum & 86.9 & 208.9 & 94.8 & 109.2 & - \\
\hline Mean & 3.476 & 8.356 & 3.950 & 4.550 & - \\
\hline Std. Deviation & 1.2444 & .9283 & 1.5472 & 1.7604 & - \\
\hline
\end{tabular}

The data above explains that the number of students in the experiment group are 25 , and the control group are 24. Range value at experiment group was lower from 4.1 at the pretest, turned to 3.0 at the posttest. Otherwise in control group, the range increased from 4.3 at the pretest turned to 5.7 at the posttest. This indicated that the range data from experiment group was getting narrower but in the control group it was getting wider.

The minimum score at experiment group also increased from 2.0 to 6.8, meanwhile at control group the minimum score was still 2.0. The same things happened in maximum scores as well, where at the experiment group it significantly increased from 6.1 to 9.8 , but at control group only from 6.3 to 7.7. The total score at experiment group improved significantly from 86.9 to 208.9, but at control group from 94.8 turn to 109.2 only. The mean scores also significantly improved at experiment group which was 3.476 turns to 8.356 , but at control group turns to 4.550 from 3.950.

On the standard deviation at experiment group, it decreased to 0.9238 at the posttest from 1.2444 at the pretest, and at control group it increase 1.7604 at posttest from 1.5472 at the pretest. This proved that the range between the scores with the mean scores for the experiment group was closer than the control group.

d. Calculation of the normalized gain score on the pretest and posttest at experiment and control group can be seen from the table below: 
Volume 5, Number 02, December 2019

Table 7. Normalized gain score

\begin{tabular}{|c|c|}
\hline $\begin{array}{l}\text { Normalized gain score } \\
\text { of experiment group }\end{array}$ & $\begin{array}{c}\text { Normalized gain score } \\
\text { of control group }\end{array}$ \\
\hline 0,67 & 0,07 \\
\hline 0,95 & 0,05 \\
\hline 0,89 & 0,20 \\
\hline 0,69 & 0,43 \\
\hline 0,85 & 0,38 \\
\hline 0,68 & 0,08 \\
\hline 0,70 & 0,22 \\
\hline 0,91 & 0,22 \\
\hline 0,68 & 0,00 \\
\hline 0,66 & 0,03 \\
\hline 0,63 & 0,14 \\
\hline 0,66 & 0,11 \\
\hline 0,60 & 0,00 \\
\hline 0,75 & 0,04 \\
\hline 0,93 & 0,14 \\
\hline 0,93 & 0,07 \\
\hline
\end{tabular}


Novalia Tanasy, Nuraliah Ali, Improving the Vocabulary mastery...

\begin{tabular}{ll}
0,73 & 0,07 \\
0,73 & 0,06 \\
0,58 & 0,04 \\
0,90 & 0,16 \\
0,89 & 0,07 \\
0,71 & 0,16 \\
0,86 & 0,03 \\
0,73 & 0,00 \\
0,80 & \\
\hline
\end{tabular}

Table 7 informs us that at experiment group, the lowest normalized gain score was 0.58 and the highest was 0.95 . These are very different from the control group where the lowest normalized gain score was 0.00 and the highest was only 0.43 . Result from table above also declares us that the highest normalized gain score at the experiment group is categorized as high as classified in table 8 below:

Table 8. Normalized gain score category

\begin{tabular}{cc}
\hline Interval & Category \\
& \\
\hline$<\mathrm{g}>{ }^{3} 0,70$ & High \\
$0,30<<\mathrm{g}><0,70$ & Medium \\
$<\mathrm{g}>\leq 0,30$ & Low \\
& \\
\hline
\end{tabular}




\section{Volume 5, Number 02, December 2019}

Table 9. Descriptive analysis result of normalized gain score

\begin{tabular}{|c|c|c|c|}
\hline & $\begin{array}{c}\text { Normalized } \\
\text { gain score } \\
\text { at experiment group }\end{array}$ & $\begin{array}{l}\text { Normalized } \\
\text { gain score } \\
\text { at control group }\end{array}$ & Valid N (listwise) \\
\hline $\mathrm{N}$ & 25 & 24 & 24 \\
\hline Range & .37 & .43 & \\
\hline Minimum & .58 & .00 & \\
\hline Maximum & .95 & .43 & \\
\hline Sum & 19.10 & 2.76 & \\
\hline Mean & .76 & .12 & \\
\hline Std. Deviation & .11551 & .11075 & \\
\hline
\end{tabular}

The data analysis above illustrates us that range at normalized gain score at the experiment group was 0.37 which is smaller than the normalized gain score in the control group which was 0.43. For the minimum and maximum scores, we can see that the normalized gain score at experiment group were 0.58 and 0.95 , this means it is higher than normalized gain score in the control group which were 0.00 and 0.43 only.

For the standard deviation on normalized gain score at experiment group was 0.115511 whereas normalized gain score in the control group was 0.11075 , where these scores were not so different, which indicates that the scattered data of both groups were the same.

Then the mean score on normalized gain score at experiment group was 0.76 which is categorized as high. Meanwhile the mean score on normalized gain score at control group wass 0.12 which is still categorized as low. 
e. Finding out the students interest or attitude towards learning vocabulary by using WordConnection game can be measured by distributing questionnaires to the experiment group after giving the posttest. The total numbers of the questionnaire were 20 numbers with close-ended model questions. The questions were answered individually within 30 minutes. After getting the students' responds, the data then were counted. The results as below:

Table 10. Most frequent questionnaire score

\begin{tabular}{|c|c|c|}
\hline Most frequent score & Frequency & Percentage \\
\hline 85 & 6 & $24 \%$ \\
\hline 81 & 4 & $16 \%$ \\
\hline 82 & 3 & $12 \%$ \\
\hline 79 & 3 & $12 \%$ \\
\hline 88 & 2 & $8 \%$ \\
\hline 87 & 2 & $8 \%$ \\
\hline 78 & 2 & $8 \%$ \\
\hline 83 & 1 & $4 \%$ \\
\hline 89 & 1 & $4 \%$ \\
\hline 72 & 1 & $4 \%$ \\
\hline Total & 25 & $100 \%$ \\
\hline
\end{tabular}

Table 9 above explains that 6 students (24\%) got 85 score, and those were the most frequent. Then 4 students $(16 \%)$ got 81 score. Then 3 students $(12 \%)$ got 82 , also 3 students (12\%) 79. 2 students (8\%) got 88, 2 other students $(8 \%)$ got 87 and another 2 students $(8 \%)$ got 78 . For score 83, 89 and 72 each got 1 student (4\%). 


\section{Volume 5, Number 02, December 2019}

f. After checking the result above, we classified the students' questionnaire attitude by using Likert scale below. The results are:

Table 11. The students' attitude toward the use of Word-Connection game

\begin{tabular}{lccc}
\hline \multicolumn{1}{c}{ Classification } & Range of score & Frequency & Percentage \\
\hline Strongly positive & $85-100$ & 11 & $44 \%$ \\
Positive & $69-84$ & 14 & $56 \%$ \\
Fairly positive & $53-68$ & - & - \\
Negative & $37-52$ & - & - \\
Strongly Negative & $20-16$ & - & - \\
\hline Total & & & \\
\hline
\end{tabular}

In relation to the questionnaire above, there were 11 students or $44 \%$ whose score categorized as Strongly positive and 14 students or 56\% whose categorized as Positive. These data mean that most of the students had Positive attitude toward the use of Word-Connetion game as supportive learning media.

g. After achieving the frequency and the percentage from the result of the questionnaire forms above, the mean score was counted as follows:

Table 12. The mean score of the students attitude

\begin{tabular}{cc}
\hline Group & Mean score \\
\hline Experiment & 82.68 \\
\hline
\end{tabular}

Table above clearly tells us that the mean score of the students attitude at the experiment group was 82.68, which means that the students had positive agreement or statement about applying Word-Connection game in the learning process. 


\section{Discussion}

\section{a. Students vocabulary achievement}

Based on the written test on vocabulary, it is revealed that the students pretest results were very low at both groups. Mean score that the treatment group achieved was 3.476 on the pretest, where $76 \%$ or 19 students were categorized as Very poor, $12 \%$ or 3 students were categorized as Poor and $12 \%$ or 3 students were categorized as Fair. Meanwhile control group actually got better mean score on the pretest which was 3.950, where $54 \%$ or 13 students were categorized as Very poor, $25 \%$ or 6 students were categorized as Poor and $21 \%$ or 5 students were categorized as Fair. But otherwise after the treatment on the posttest, the treatment group achieved significant improvement mean score which was 8.356 where $12 \%$ or 3 students were categorized as Fairly good, $48 \%$ or 12 students were categorized as Good, $24 \%$ or 6 students were categorized as Very good and $16 \%$ or 4 students were categorized as Excellent. In this section no more students were categorized as Very poor and Poor. Too bad for the control group could not make way better improvement. Their mean score was 4.550 where $42 \%$ or 10 students were still categorized Very poor, $21 \%$ or 5 students were categorized as Poor, $25 \%$ or 6 students were categorized as Fair, $4 \%$ or 1 student were categorized as Fairly good and $8 \%$ or 2 students were still categorized as Very poor.

A significant difference results also were found on normalized gain score where at the experiment group the result was 0.76 which was categorized as high and at the control group was 0.12 only which was categorized as low. This means that after being treated with Word-Connection game, the experiment group got better effect and achievement in learning vocabulary instead of the control group.

Actually conventional method still can be used in teaching vocabulary, but this research strengthen that adding improvisation by using games can help the students get better results significantly. This is parallel to what Eker \& Karadeniz (2014) stated that it's very important that students discover fun and enjoyable aspect of the course and they participate in the lesson actively that can provide more meaningful learning for them by creating discussion environment.

Further, Tanasy (2017) stated that the aim of education is to train the students who participate in the lesson actively and can create alternative ways or stimulation to solve a problem and can think critically, was actually correct. Because while doing this research, the writers 


\section{Volume 5, Number 02, December 2019}

several times stimulated the students by giving some clues about the secret or hidden words or allowing them to check up in dictionary. The students really faced a serious problem in the early meetings that they had very less knowledge of vocabulary or weak in memorizing the words, especially in the experiment group which got even lower sum total scores in the pretest which was 86.9 only compares to control group with sum total scores 94.8. But implying Word-Connection game at the end of the learning process, affected the students at the experiment group better result in mastery vocabulary and excited classroom situation.

\section{b. The students' attitude towards Word-Connection game}

Data obtained from the questionnaire forms explained to us that $44 \%$ of students attitude were classified as Strongly positive and $56 \%$ as Positive with mean score 82.68 . This indicated that the students had positive agreement or statement towards the use of Word-Connection game in learning vocabulary. This is similar to Hallajian (2016) finding that it can be concluded that games have some positive aspects and effects, it can be noted to boost creativity. It should be noted that students who use a certain amount of games experience creativity increase and critical thinking.

While learning, the students expect some fun. This is why the role of vocabulary game cannot be denied. However, according to Al Masri \& Al Najar (2014), in order to achieve the most from vocabulary games, it is important that suitable games are chosen. Whenever a game is to be conducted, the number of students, proficiency level, cultural context, timing, learning topic and the classroom settings are factors that should be taken into account. For English Education Department at Universitas Muslim Maros experienced, Word-Connection game helps enough to get better achievement, positive attitude and useful tool in mastery vocabulary. Eventually, the writers determined that the use of Word-Connection game can be used in learning process to improve the students' vocabulary and positive attitude instead of using the conventional method only.

\section{E. CONCLUSION}

Related to findings, the writers finally brought conclusions that the use of Word-Connection game can improve the students vocabulary mastery at class $1 \mathrm{~A}$ as the experiment group of English education department of Universitas Muslim Maros. While doing the treatment, the students really helped the writers by their excitement and motivation in following the game. They also felt disappointed when the writers announced that the treatment was over. As a suggestion, the writers suggest that the teachers of English education department should try the Word-Connection game 
Novalia Tanasy, Nuraliah Ali, Improving the Vocabulary mastery...

to improve the students' vocabulary mastery or consider to vary it to get more excitement and creativity in the learning process.

\section{REFERENCES}

Abidin, Z., \& Purbawanto, S. (2015). Pemahaman Siswa terhadap Pemanfaatan Media Pembelajaran Berbasis Livewire pada Mata Pelajaran Teknik Listrik Kelas X Jurusan Audio Video di SMK Negeri 4 Semarang. Edu Elektrika Journal. 4 (1). Retrieved May 6, 2019, from https://journal.unnes.ac.id/sju/index.php/eduel/article/view/7800

Akdogan, E. (2017). Developing Vocabulary in Game Activities and Game Materials. Journal of Teaching and Education. 7 (1). Retrieved May 6, 2019, from https://www.researchgate.net/publication/322291866_DEVELOPING_VOCABULARY _IN_GAME_ACTIVITIES_AND_GAME_MATERIALS

Ali, N. \& Tanasy, N. (2018). Analisis Kinerja Guru PAI dalam Penerapan Metode Prompts pada Penyandang Disabilitas di SLB A YAPTI Makassar. Jurnal Inspiratif Pendidikan. 7 (2). Retrieved May 8, 2019 from http://journal.uin-alauddin.ac.id/index.php/InspiratifPendidikan/article/view/7854

Alqahtani, M. (2015). The Importance of Vocabulary in Language Learning and How to be Taught. International Journal of Teaching and Education. III (3). Retrieved April 28, 2019, from https://www.iises.net/international-journal-of-teaching-education/publication-detail-213

Chiramanee, T. (2014). Vocabulary Learning Strategies of Thai University Students and Its Relationship to Vocabulary Size. International Journal of English Language Education. 2 (1). Retrieved April 28, 2019 from http://free-journal.umm.ac.id/files/file/5366-19428-2PB.pdf

Derakhshan, A,. \& Khatir, E D. (2015). The Effects of Using Games on English Vocabulary Learning. Journal of Applied Linguistics and Language Research. 2 (3). pp. 39-47. Retrivied May 7, 2019, from https://pdfs.semanticscholar.org/774c/2cae6b8aefbe2fdcf88c151d0441bebba857.pdf

Ebrahimi, Z., \& Azhideh, P. (2015). The Effects of Teaching Vocabulary Learning Strategies on Iranian EFL Learners 'Vocabulary Development. International Journal on Studies in English Language and Literature (IJSELL). 3 (1). Retrieved May 27, 2019, from https://www.davidpublisher.org/index.php/Home/Article/index?id=35806.html 


\section{Volume 5, Number 02, December 2019}

Eker, C., \& Karadeniz, O. (2014). The Effects of Educational Practice with Cartoons on Learning Outcomes. International Journal of Humanities and Social Science. 4 (14). Retrieved May 26, 2019, from http://www.ijhssnet.com/journals/Vol_4_No_14_December_2014/25.pdf

Gay, L.R, et al. (2012). Educational Research, Competencies for Analysis and Application. Ohio: Merril Publishing.

Hallajian, M., \& Tabatabayi, A. (2016). The Effects of Computer Games on Increasing Students' Creative Thinking. International Journal of Humanities and Cultural Studies. 1 (1). Retrieved May 26, 2019, from https://www.ijhcs.com/index.php/ijhcs/article/view/634

Jafarian, R B., \& Shoari, E. (2017). The Effect of Games on Iranian Young EFL Learners' Vocabulary Learning. European Journal of English Language and Literature Studies. 5 (5), pp.12-24. Retrieved April 23, 2019, from http://www.eajournals.org/wp-content/uploads/TheEffect-of-Games-on-Iranian-Young-EFL-Learners\%E2\%80\%99-Vocabulary-Learning.pdf Masri, A, A., \& Najar, M, A. (2014). The Effect of Using Word Games on Primary Stage Students Achievement in English Language Vocabulary in Jordan. American International Journal of Contemporary Research. 4 (9). Retrieved May 25, 2019, from http://www.aijcrnet.com/journals/Vol_4_No_9_September_2014/17.pdf

Rizki, S M et al. (2013). The Use of Picture Games to Improve Students' Motivation in Learning Vocabulary. English Education Journal. 3 (2). Retrieved April 19, 2019, from https://journal.unnes.ac.id/sju/index.php/eej/article/view/2716

Sugiyono. (2015). Metode Penelitian Pendidikan Pendekatan Kuantitatif, Kualitatif dan R $\mho D$. Bandung: AlfaBeta. 